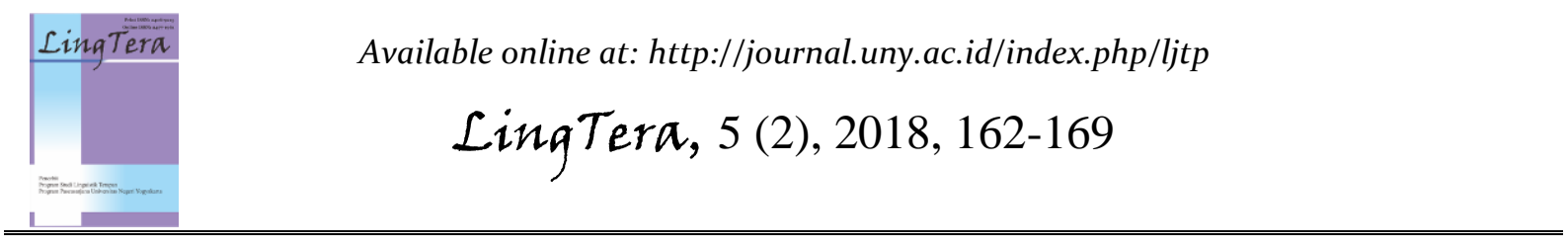

\title{
Pembelajaran bahasa Inggris for specific purposes
}

\author{
Aniceto Jordão de Araújo \\ STM Negeri Dili. Desa Becora, Kecamatan Dili Timur, Kabupaten Dili, Timor Leste \\ * Coresponding Author. E-mail: anicetomethajordao@gmail.com \\ Received: 29 August 2016; Revision: 10 November 2018; Accepted: 31 December 2018
}

\begin{abstract}
Abstrak
Penelitian ini bertujuan untuk mengungkapkan profil STM Negeri Dili Timor Leste, guru bahasa Inggris, dan pihak-pihak yang terkait dengan pembelajaran bahasa Inggris; dan proses pembelajaran bahasa Inggris for specific purposes. Metode penelitian ini adalah deskriptif kualitatif. Subjek penelitian ini adalah guru-guru bahasa Inggris, siswa/i kelas XI dan XII STM Negeri Dili serta dua orang penanggungjawab kurikulum dari Kementerian Pendidikan Timor Leste. Pengumpulan data melalui wawancara, observasi, dokumentasi, dan angket. Analisis data dengan klasifikasi data, transkripsi, verifikasi, dan kesimpulan. Hasil penelitian menunjukkan bahwa pembelajaran bahasa Inggris for specific purposes tidak didukung oleh kemampuan sumber daya manusia dan kreativitas guru, perangkat pembelajaran, pelatihan bagi guru bahasa Inggris yang relevan, peningkatan kesejahteraan dan kinerja; serta budaya dan lingkungan dalam proses pembelajaran siswa.

Kata Kunci: pembelajaran, bahasa Inggris, pembelajaran for specific purposes
\end{abstract}

\section{The learning of English for specific purposes}

\begin{abstract}
This study aims to reveal the profiles of STM Negeri Dili, Timor Leste, English teachers, and parties related to the English learning; and the English learning process for Specific Purposes. The study employed the qualitative descriptive method. The research subjects were English teachers, male and female students of Grades XI and XII of STM Negeri Dili, Timor Leste, and two people in charge of curriculum the Ministry of Education of Timor Leste. The data were collected by interview, observation, documentation, and a questionnaire. The data analysis through data classification, transcription, verification and conclusion drawing. The results of the study show that the learning of English for Specific Purposes is not supported by the human resources' competencies, teachers' creativity, learning kits, the training for English teachers is relevant, improvement of welfare and performance, culture and environment in students' learning.
\end{abstract}

Keywords: learning, English, learning for specific purposes

How to Cite: de Araujo, A. (2018). Pembelajaran bahasa Inggris for specific purposes. LingTera, 5(2), 162-169. doi:https://doi.org/10.21831/lt.v5i2.10700

https://doi.org/10.21831/lt.v5i2.10700

\section{PENDAHULUAN}

Upaya mengantisipasi penginstalasian pipa minyak dengan teknologi modern dan masuknya perusahaan asing yang go international, maka dunia pendidikan khususnya STM harus menyesuaikan kurikulum, silabus dan modul dengan tuntutan dan kebutuhan. Hal ini dimaksudkan agar terdapat kesesuaian antara teori pengetahuan dari kosakata bahasa teknik di kelas dengan tools, materials, dan equipments saat praktik di bengkel.
Dengan melihat kenyataan bahwa selama ini, buku ajar yang digunakan dalam proses pembelajaran bahasa Inggris for Specific Purposes di STM itu berbeda-beda. Hal ini diharapkan akan dilakukan koordinasi dan pertemuan dengan perwakilan dari STM Swasta Fatumaca. Pertemuan ini dimaksudkan untuk menyepakati keseragaman penggunaan buku ajar bahasa Inggris untuk Sekolah Teknologi Menengah Kejuruan. Buku ajar tersebut adalah New Concept, English, Teaches Integrated Language Skills for SMK, untuk bidang keahlian teknik mesin, teknik elektro, dan teknik bangunan. Hasil keputusan 


\section{LingTera, 5 (2), 2018 - 163}

Aniceto Jordão de Araújo

dari pertemuan beserta buku ajar tersebut disampaikan kepada Direktur Kurikulum Nasional Kementerian Pendidikan dan Kebudayaan Timor Leste. Buku ajar tersebut, kemudian oleh bagian Kurikulum Nasional untuk sementara dijadikan sebagai buku ajar dan pegangan bagi guru dan siswa Sekolah Teknologi Menengah Kejuruan. Perlu diketahui bahwa proses pendidikan di Timor Leste terus berjalan setelah lepas dari NKRI pada tahun 1999. Sekolah-sekolah yang dulunya ditinggalkan Indonesia difungsikan kembali dan proses pembelajaran (masih) menggunakan kurikulum Indonesia. Dengan demikian, secara otomatis dalam proses aktivitas belajar mengajar pun menggunakan bahasa Indonesia.

Hal lain yang melatarbelakangi penulisan ini, yakni adalah proyek rehabilitasi total gedung sekolah oleh KOICA. Semua fasilitas dan sarana prasarana bengkel akan disediakan termasuk kurikulum yang akan digunakan di sekolah ini. Menurut mereka, sekolah ini akan dijadikan sebagai sekolah pilot yang bertaraf internasional di bidang teknik. Mereka juga memaparkan rencana jangka pendek, menengah, dan panjang terutama yang berkaitan dengan para lulusan sekolah ini. Pemerintah Korea Selatan mengatakan bahwa "apabila siswa-siswanya sudah lulus dari sekolah ini bisa langsung bekerja pada perusahaan-perusahaan di Korea Selatan".

Seiring dengan itu, saat ini proses pengiriman guru-guru untuk mengikuti pelatihan di bidang teknik ke Korea Selatan sedang berlangsung secara bertahap. Pada proses ini bahasa pengantarnya adalah bahasa Inggris. Jadi, mata pelajaran bahasa Inggris for Specific Purposes sangat memainkan peran penting di dalam mendukung pembelajaran kosakata teknik. Berkaitan dengan masalah sinkronisasi pembelajaran antara teori dan praktik, semenjak tahun 2000 hingga sekarang Kementerian Pendidikan Timor Leste belum mempunyai kurikulum untuk Sekolah Kejuruan dan Sekolah Teknologi Menengah khususnya.

Dalam hal ini, kurikulum sekolah kejuruan berbeda dengan kurikulum sekolah umum. Kurikulum pendidikan kejuruan disesuaikan dengan fungsi dan tujuan pendidikan. Relevansinya dengan kurikulum sekolah teknologi kejuruan adalah sebagai berikut. Dalam Decree Law Nomor 8/2010 Republik Demokratik Timor Leste dikatakan bahwa tujuan sekolah kejuruan adalah (a) berkontribusi pada pengembangan pribadi generasi muda dengan memberikan, antara lain, persiapan yang sesuai dengan kehidupan kerja; (b) penguatan, model alternatif sistem pendidikan formal, mekanisme pendekatan antara sekolah dan dunia kerja; (c) memfasilitasi generasi muda dengan dunia kerja dan pengalaman profesional; (d) memberikan pelayanan langsung kepada masyarakat, atas dasar penaikan timbal balik (reciprocal valorization); (e) negara menyediakan sumber daya manusia yang dibutuhkan dalam perspektif pembangunan nasional, regional, dan lokal; (f) Menyiapkan generasi muda dengan maksud untuk menyatukan mereka ke dalam kehidupan atau studi lebih lanjut bekerja dalam bentuk kualifikasi profesional; (g) Memberikan pengembnagan terintegrasi pada generasi muda, menyampaikan informasi dan orientasi profesional, serta transisi pada kehidupan kerja, dalam bentuk inisiasi profesional (República Democrática de Timor-Leste, 2010, p.2).

Perbedaan signifikan antara metode pembelajaran bahasa Inggris untuk Sekolah Menengah Umum dan Sekolah Kejuruan, khususnya Sekolah Teknologi Menengah adalah sebagai berikut. (1) Tujuan pembelajaran bahasa Inggris di SMU adalah mengembangkan kemampuan berkomunikasi dalam bahasa Inggris dalam bentuk lisan maupun tertulis; (2) Bahasa Inggris for Specific Purposes menekankan pada bahasa Inggris spesial yang memiliki disiplin khusus (particular disciplines), pekerjaan (occupation) atau kegiatan (activity). Dengan demikian, secara umum metode pembelajaran struktur kalimatnya sama dan tetap mengikuti kaidah-kaidah kebahasaan. Berkaitan dengan proses pembelajaran bahasa Inggris for specific purposes (teknik) secara mendasar memprioritaskan pada kemampuan siswa untuk mengidentifikasi alat-alat dan mesinmesin (Tools and Machine Equipments) yang umumnya berkosakata bahasa Inggris (sebagian berkosakata bahasa German) serta bagaimana cara dan fungsinya di dalam mengopersikannya. Metode ini akan sangat bermanfaat dan berguna ketika para siswa telah lulus dengan berbekal pengetahuan bahasa Inggris for specific purposes di bidang teknik. Semua itu akan menjadi realita, jikalau mereka bekerja di pabrik dan perusahaan besar yang berteknologi canggih. Tentu saja, mereka akan berhadapan dengan bahasa Inggris for specific purposes (teknik) seperti yang terdapat pada alat-alat dan mesin-mesin maupun pada tingkat pengoperasianya (Instructions of Operational System).

Dalam ranah pembelajaran, betapapun bagusnya sebuah kurikulum tetapi kalau karakter manusianya tidak ada perubahan, maka segala usaha akan sia-sia tanpa hasil (Purwanti, 2016; 


\section{LingTera, 5 (2), 2018 - 164}

Aniceto Jordão de Araújo

Nurmalasari, 2011). Hal ini mengimplikasikan bahwa budaya orang Timor Leste yang suka berpesta dan berdansa turut berkontribusi dalam mempengaruhi karakter siswa untuk belajar berkompetisi. Faktor keluarga dan lingkungan juga turut mengambil bagian dalam pembentukan karakter siswa (Harianti, \& Amin, 2016; Islam, 2017). Jika para orang tua tidak memperhatikan anak-anaknya, maka kehidupan pendidikannya juga terabaikan. Dengan berpesta dan berdansa semalam suntuk, mereka akan merasa mengantuk dan malas untuk pergi ke sekolah. Oleh karena itu penelitian ini dilakukan untuk mengungkapkan profil STM Negeri Dili Timor Leste, guru bahasa Inggris, dan pihak-pihak yang terkait dengan pembelajaran bahasa Inggris, dan proses pembelajaran bahasa Inggris for specific purposes.

\section{METODE}

Penelitian ini menggunakan jenis penelitian deskriptif kualitatif. Objek dalam penelitian ini adalah objek alamiah (natural setting) yang ada di STM Negeri Dili, Timor Leste. Penelitian ini dilakukan di STM - kelompok Teknologi dan Industri Negeri Dili, Timor Leste. Sekolah ini terletak di Dusun Caceu Laran, Desa Becora, Kecamatan Cristo Rei, Kabupaten Dili, Timor Leste. Penelitian ini dilakukan pada tanggal 13 Januari sampai 13 Februari 2016. Pada penelitian ini yang menjadi subjek pengumpulan data adalah tiga orang guru yang masih aktif mengajar bahasa Inggris dan dua orang dari Kementerian Pendidikan Timor Leste serta 120 siswa/i kelas XI dan XII (angket pernyataan) juga dijadikan unit analisisnya.

Prosedur penelitiannya adalah menghasilkan data-data deskriptif berupa kata-kata tertulis atau lisan didasari oleh perilaku orang yang diamati. Pemerolehan data dilakukan dengan (1) observasi; (2) wawancara dengan tiga orang guru bahasa Inggris dan dua orang dari kementerian pendidikan serta beberapa orang siswa kelas XI dan XII; (3) dokumentasi langsung di lapangan untuk melengkapi data-data yang berhubungan dengan penelitian. Data penelitian ini diperoleh dengan teknik wawancara secara mendalam dengan informan sebagai bentuk pencarian data dan dokumentasi langsung dilapangan.

Instrumen dalam penelitian ini adalah (1) peneliti sendiri sebagai instrumen yang memantau langsung di lapangan; (2) pertanyaan penelitian untuk guru-guru bahasa Inggris dan pihakpihak terkait dengan pembelajaran bahasa Inggris; (3) alat perekam; (4) angket pernyataan penelitian siswa; dan (5) kamera foto.
Teknik pengumpulan data dilakukan dengan teknik: participant observation (mengamati langsung objeknya), wawancara (In Depth Interview), dokumentasi (Sugiyono, 2013, p.309) dan kuesioner (Sugiyono, 2015, p.192).

\section{Teknik Analisis Data}

Komponen-komponen dalam analisis data (interactive model) (1) Data reduction (reduksi data). Data yang sudah diperoleh peneliti dianalisis dengan mereduksi data; (2) Data display (penyajian data). Setelah data direduksi, langkah berikutnya peneliti akan menyajikan data. Penyajian data dilakukan dalam bentuk uraian singkat berupa transkripsi wawancara, hasil angket siswa, dan foto; (3) Conclusion drawing atau Verification (kesimpulan). Langkah terakhir adalah penarikan kesimpulan dan verifikasi. Kesimpulan awal yang dikemukan masih bersifat sementara dan akan berubah bila tidak ditemukan bukti-bukti kuat yang mendukung pada tahap pengumpulan data berikutnya. Berdasarkan data hasil penelitian yang dilakukan di Sekolah Teknologi Menengah Negeri Dili, Timor Leste bahwa data hasil penelitian sesuai dengan rumusan masalah.

\section{HASIL DAN PEMBAHASAN}

\section{Profil STM Dili, Guru Bahasa Inggris, dan Pihak-Pihak yang Terkait dengan Pembelajaran Bahasa Inggris}

Pembangunan gedung Sekolah Teknologi Menengah ini diresmikan pada tanggal 2 November 1988 oleh Presiden Republik Indonesia, Soeharto. Sekolah ini pada zaman Indonesia bernama STM Negeri Dili. Lokasinya terletak di Desa Becora, Kecamatan Dili Timur, Kabupaten Dili, Provinsi Timor Timur. Pada awal diresmikan sekolah ini menpunyai lima jurusan, yakni jurusan: Bangunan, teknik pengerjaan logam, Otomotif, Listrik, dan Elektronik. Di awal kemerdekaan pada tahun 2000 nama STM berganti nama menjadi Sekolah Teknik Kejuruan (ETV) Dili sampai tahun 2002. Kemudian pada tahun 2003-2005 berganti lagi namanya dari ETV menjadi Escola Técnica Professional (ETP)/ (Sekolah Teknik Profesional) Becora. Selanjutnya, pada tahun 2006-2012 dengan menambahkan Grupo de Tecnólogia e Indústria (GTI)/ Kelompok Teknologi dan Industri) sehingga menjadi Escola Técnica Professiónal-Grupo de Técnologia e Indústria (ETP-GTI)/Sekolah Teknik Profesional-Kelompok Teknologi dan Industri. Pergantian terakhir, pada tahun 2013 sampai 


\section{LingTera, 5 (2), 2018 - 165}

Aniceto Jordão de Araújo

sekarang dengan nama Escola Secundária Técnica Vocaçional (ESTV)/Sekolah Teknik Menengah Kejuruan. Namun, sesudah memasuki tahun 2000-an bertambah lagi satu jurusan, yaitu jurusan Informatika. Dengan demikian, sekolah ini secara total mempunyai enam jurusan pada saat ini.

Menjadi guru bahasa Inggris bukanlah pekerjaan yang mudah. Oleh karena bahasa adalah alat komunikasi apalagi bahasa Inggris yang merupakan bahasa asing. Tidak mudah mempelajari bahasa yang vocabulary, grammar dan cara pengucapannya jauh berbeda dengan bahasa ibu kita, bahasa Tetun. Mereka selalu menemui kendala dalam pembelajaran materi ini. Hal ini terjadi karena mereka tidak mempunyai pengalaman mengajar bahasa Inggris teknik sebelumnya. Selain masalah tersebut juga terdapat kendala-kendala lain dari berbagai aspek seperti tidak adanya kurikulum, bahan ajar (salah satunya buku ajar bahasa Inggris Teknik), pelatihanpelatihan, dan peningkatan kesejahteraan. Aspekaspek inilah yang menjadi pemicu bagi pembelajaran materi ini tidak maksimal. Kendalanya pertama guru tidak menguasai materi pembelajaran bahasa Inggris for specific purposes, narasumber PF jujur mengatakan bahwa "Karena bahasa Inggris teknik saya tidak menguasai keseluruhannya. Saya mencoba untuk menguasainya karena itu tugas utama saya" (W2/PF/210116/P40). Kedua, guru tidak mempunyai pengalaman guru bahasa Inggris for specific purposes, kata PF (W1/TV/130216/P16); ketiga, kondisi keluarga guru.

Pihak-pihak yang terkait dengan pembelajaran bahasa Inggris tidak memprioritaskan pembelajaran English for Specific Purpose karena kurangnya pengetahuan yang disebabkan oleh faktor tidak adanya sumber daya manusia (SDM). Sejalan dengan itu Eko M (2016) mengatakan bahwa ketertarikan orang mempelajari bahasa Inggris, karena adanya tugas atau pekerjaan tertentu dengan menggunakan bahasa Inggris. Dalam hal ini, pihak kementerian pendidikan tidak mempunyai program untuk menyelesaikan permasalahan terutama masalah tentang pembelajaran bahasa Inggris for specific purposes di STM Negeri Dili.

\section{Kreativitas Guru dalam Pembelajaran Bahasa Inggris for Specific Purposes}

Pembelajaran bahasa Inggris for Specific Purposes (teknik) sesuai dengan kompetensi siswa. Kebutuhan siswa dalam pembelajaran harus disesuaikan dengan keahlian mereka. Dalam hal ini kurikulum menjadi panduan pembelajaran. Namun, ada atau tidaknya panduan tersebut bukan berarti para guru harus mengesampingkan kebutuhan dan tuntutan pasar. Muncul pertanyaan apakah pembelajaran materi ini sudah relevan dengan kompetensi siswa? PF menuturkan bahwa "Itulah yang terjadi di sini. Kami hanya sebagai seorang guru walaupun latar belakang kami adalah bahasa Inggris umum tapi dengan kondisi-kondisi yang ada, materi-materi yang ada kami mencoba untuk mengajarnya pada mereka dan kami banyak berkonsultasi dengan temanteman yang berpengalaman guru bahasa Inggris di sekolah teknik ini, karena bahasa Inggris for Technical High School different, berbeda dengan sekolah-sekolah umum" (W1/PF/140116/P18). Pengelolaan waktu dalam pembelajaran bahasa Inggris for Specific Purposes. Pengelolaan waktu dalam suatu kegiatan itu sangat penting karena kita dapat memanfaatkan waktu lebih efesien dan terarah. Pembelajaran ini dialokasikan waktu efektif tiga jam/pertemuan di kelas. Ada informan yang mengatakan waktu tiga itu cukup tetapi ada pula yang mengatakan kurang cukup. Informan PF mengemukakan bahwa "Cukup. Cukup untuk bahasa Inggris". Lebih lanjut, peneliti mengajukan pertanyaan "Bagaimana sistem pengelolaan untuk tiga jam setiap pertemuan?" Dia menjawab "kami mengajar berdasarkan pengalaman yang ada. Awal-awal pembelajaran kami ... buat jam masuk berapa jam yang kami alokasi untuk masing-masing warming up. Adapun untuk mengajar untuk diskusi-diskusi. Jadi, kami berdasarkan pengalaman yang ada. Jadi, itu yang kami alokasikan sampai tiga jam itu". Untuk memastikan waktu berapa menit yang dialokasikan untuk tiap sesi, peneliti terus mengajukan pertanyaan kepastian kepada informan yakni "Berarti secara sistematis pengelolaan kelas tiga jam itu belum terjadi?" tanya peneliti. Informan menjawab "Secara sistematis belum. Itu yang kami lakukan hanya berdasarkan pengalaman" (W1/PF/140116/P5).

\section{Proses Pembelajaran Bahasa Inggris di STM Negeri Dili}

Proses pembelajaran bahasa Inggris berdasarkan angket penelitian menunjukkan bahwa mayoritas siswa mengatakan guru "tidak pernah" mengajar bahasa Inggris for specific purposes (teknik) atau sekitar 33,3\% siswa yang mengatakan "tidak pernah", $27.5 \%$ mengatakan 'jarang', dan 30\% mengatakan "kadang-kadang", $0.8 \%$ mengatakan "sering", serta siswa yang mengatakan "selalu" adalah $8.3 \%$. Jadi proses pembel- 


\section{LingTera, 5 (2), 2018 - 166}

Aniceto Jordão de Araújo

ajarannya tidak ada relevansinya dengan kebutuhan siswa sebagai sekolah teknologi kejuruan sehingga sangat kontradiktif dengan kebutuhan jenis sekolah ini.

Mengatasi pembelajaran bahasa Inggris di STM agar sesuai dengan kebutuhan siswa. Upaya untuk mengatasi permasalahan Pembelajaran bahasa Inggris for specific purposes dengan peralatan teknik adalah dengan metode pembelajaran kombinasi dan terpadu. Menurut saya, sebaiknya ada dulu guru-guru teknik untuk seluruh Timor Timur supaya mereka itu berunding dulu agar memperbaiki kurikulum teknik itu sendiri sesuai dengan kebutuhan anak. Sampai sekarang belum ada sehingga ada sinkronnya di situ..." (W1/FF/130116/P24).

Pengelolaan waktu dalam proses pembelajaran bahasa Inggris for Specific Purposes. Mengenai pembagian waktu selama dalam aktivitas pembelajaran itu tergantung pada metode dan strategi guru. Pengelolaan waktu juga tergantung pada tingkat kesulitan materi yang akan disampaikan. Oleh karena dalam pembelajaran bahasa Inggris for specific purposes di sekolah teknologi industri diterapkan metode pembelajaran terpadu, yakni antara pembelajaran kosakata bahasa Inggris teknik dengan tools, materials dan equipments teknik.

\section{Pemanfaatan Perangkat Pembelajaran dalam Pembelajaran Bahasa Inggris di STM Negeri Dili, Timor Leste}

Pembuatan Silabus, Rencana Pelaksanaan

Pembelajaran (RPP) atau Satuan Acara

Pembelajaran (SAP)

Salah satu tugas guru dalam proses pembelajaran adalah menyusun silabus dan Rancangan Pelaksanaan Pembelajaran (RPP). Guru dapat merancang materi pada silabus sesuai dengan kebutuhan peserta didik. Dengan adanya silabus dan RPP, seorang guru tidak bisa menyelewengkan waktu untuk mengajar dan topik atau sub topik mata pelajaran yang telah tertulis tidak bisa dilewatkan. Akan lebih baik, jika silabus dan RPP yang sudah siap diberikan kepada siswa. Berdasarkan hasil wawancara dengan narasumber guru-guru bahasa Inggris di sekolah ini pun memberikan jawaban yang sama, yakni mereka tidak membuat silabus dan RPP walaupun sudah diberitahu oleh pihak sekolah. Adapun alasan, mereka tidak membuatnya karena berkaitan dengan Avaliação Desémpenho (Penilaian Kinerja) yang selama ini dilakukan tetapi tidak ada manfaatnya sampai sekarang. Adapun maksud dari pernyataan "tidak ada manfaatnya" adalah tidak terjadinya perubahan pada kenaikan jumlah gaji dan pangkat.

Buku Ajar dalam Pembelajaran Bahasa Inggris for Specific Purposes

Mengacu pada pertanyaan, apakah buku ajar bahasa Inggris yang digunakan sesuai dengan bidang bidang kejuruan teknik yang dipelajari siswa? Jawabannya tidak sesuai karena berdasarkan pada kebijakan kementerian pendidikan yang baru demi keseragaman materi sekolah ini pun diwajibkan menggunakan buku ajar bahasa Inggris Sekolah Menengah Umum. Berawal dari sinilah terjadi ketidaksesuaian antara isi materi dengan keahlian sebagai sekolah teknologi.

Media pembelajaran di STM Negeri Dili, Timor Leste

Bahan, alat, maupun metode atau teknik yang digunakan dalam kegiatan belajar mengajar dengan maksud agar proses interaksi komunikasi edukatif antara guru dan anak didik dapat berlangsung secara efektif dan efisien sesuai dengan tujuan pembelajaran yang dicita-citakan, yang disebut media pembelajaran. Berkaitan dengan hal tersebut, narasumber PF bahwa “....tapi dengan kenyataan sampai saat ini sama sekali tidak ada" (W1/PF/140116/P8). Jadi, peneliti melihat bahwa berdasarkan kenyataan di lapangan memang tidak terdapat satupun media pembelajaran seperti yang tersebut di atas.

Evaluasi pembelajaran bahasa Inggris for Specific Purposes

Dalam suatu proses pembelajaran yang dilakukan oleh seorang pendidik atau instruktur terhadap peserta didiknya adalah menyampaikan materi. Penyampaian materi bisa berlangsung secara trimestral atau semestral atau bisa juga hanya sebulan tergantung pada nilai kepentingannya. Berdasarkan hasil wawancara dengan para narasumber rata-rata mengatakan melakukan evaluasi diri di dalam proses pembelajaran. Berikut hasil wawancara dengan informan $\mathrm{PF}$ mengatakan "...pada akhir semester kami mengevaluasi siswa-siswa dengan kami dan ada saransaran dari siswa dan teman-teman guru kami...". Lebih lanjut dalam kaitannya dengan permasalahan evaluasi, peneliti mewawancarai PF dengan pertanyaan "Mengapa anda tidak melakukan evaluasi rutin terhadap psikologi kepribadian setiap siswa?" Dia menjawab "Kedepannya kami akan mengevaluasi secara rutin untuk membantu 


\section{LingTera, 5 (2), 2018 - 167}

Aniceto Jordão de Araújo

proses pengajaran sekolah ini” (W1/PF/140116/P13).

\section{Usaha Pemerintah dalam Peningkatan Kemampuan Guru}

Pelatihan bagi Guru Bahasa Inggris

Mengikuti pelatihan bagi guru adalah hak mutlak. Berkesempatan untuk meningkatkan kapasitasnya sebagai seorang pendidik sangat diperlukan. Namun, apa terjadi pada guru bidang studi bahasa Inggris di STM Negeri Dili, Timor Leste. Wawancara dengan seorang narasumber, yakni TV (W1/TV/130216/P44) dengan pertanyaan "Apakah guru bidang studi bahasa Inggris berkesempatan untuk mengikuti pelatihan di luar negeri? Apabila Tidak, mengapa?" TV menjawab, "Pertanyaan lucu ini sebenarnya. Sampai saat ini sudah berapa tahun, Timor Leste sudah merdeka 15 tahun sekarang masuk ke-16 tahun dan saya sudah 6 tahun ngajar di sini. Lebih lanjut peneliti bertanya "Bagaimana dengan kursus atau pelatihan yang dilakukan oleh kementerian pendidikan di dalam negeri?" Narasumber menjawab "Kalo pelatihan yang dilakukan kementerian pendidikan di dalam negeri dalam proses pelatihan nggak ada kaitan sedikitpun dengan bahasa Inggris yang kita ngajar di teknik, yang mereka ngajar itu tenses.

\section{Peningkatan Kesejahteraan dan Kinerja}

Upaya pemerinth dalam peningkatan kesejahteraan dan kinerja, yaitu: pertama, pemberian jaminan asuransi kesehatan pada guru dan keluarganya. Sebagai pegawai negeri sipil yang melayani orang banyak tentu ada resikonya. Guru sebagai salah satu elemen dari pemerintah. Oleh karena itu, jaminan kesehatan bagi setiap pegawai, maka asuransi kesehatan harus disediakan oleh pemerintah sebagai salah satu wujud tanggung jawabnya. Untuk itu peneliti mewawancarai narasumber TV dengan pertanyaan "Apakah terdapat jaminan asuransi kesehatan keluarga untuk guru, istri, anak, dan anggota keluarga lain? Apabila Tidak, mengapa?" Dia menjawab "Nggak ada, sampai sekarang ini nggak ada" (W1/TV/130216/P48).

Kedua, hasil evaluasi kinerja guru diapersiasi dengan kenaikan pangkat atau gaji. Salah satu bentuk apresiasi yakni dengan direalisaikannya promosi atau kenaikan posisi/pangkat atau gaji sebagai satu tindakan wujud nyata. Sejauhmana implementasi dari hasil penilaian kinerja seorang guru selama dia bekerja. Selanjutnya, untuk mengetahui persoalan tersebut peneliti melakukan wawancara dengan informan TV (W1/TV/130216/P49) dengan pertanyaan "Apakah hasil evaluasi kinerja guru diapresiasi dengan kenaikan pangkat atau gaji?" "Apabila Tidak, mengapa?" Dia menjawab "Kenaikan gaji kami hanya menerima gaji dari tahun 2006 sampai saat ini (2016) hanya itu yang kami terima tidak seperti pertanyaan yang diajukan". Peneliti mengajukan pertanyaan akhir "Apakah dengan jumlah gaji sekian bapak merasa sudah bisa mencukupi kebutuhan keluarga?" Itulah saya dan teman-teman kami menempatkan uang itu membuat manajemen tentang uang itu karena situasinya itu kita harus memanfaatkan manajemen dalam kehidupan kita.

Ketiga, penghasilan gaji guru dengan tingkat kebutuhannya. Penghasilan guru yang serba minim sangat berpengaruh sekali di dalam melakukan aktivitas proses belajar mengajar di sekolah. Apalagi tingkat kebutuhan primer hampir setiap hari mengalami kenaikan. Maka dari itu, terjadi ketidakseimbangan antara penghasilan dengan kebutuhan sehari-harinya. Pada akhirnya, guru harus melakukan kegiatan lain untuk mencukupi kekurangan tersebut. Dengan demikian, apa yang akan terjadi selanjutnya. Berkaitan dengan ini, peneliti mewawancarai narasumber TV (W2/TV/130216/26) dengan mengajukan pertanyaan "Apakah penghasilan yang diperoleh guru belum mampu memenuhi kebutuhan hidup keluarga?" Bagaimana upaya guru untuk memenuhi kekurangan kebutuhan tersebut?" Dia menjawab "Penghasilan yang diperoleh guru teknik saat ini di negara kita ini sama sekali nggak mampu untuk memenuhi kebutuhan kehidupan keluarga karena kita ambil contoh saja hidup di kota, disini di kota Dili.

Keempat, implikasi minimnya gaji dan tuntutan kebutuhan keluarga guru terhadap proses pembelajaran di sekolah. Tuntutan kebutuhan di dalam keluarga merupakan sesuatu yang harus dan wajib dipenuhi serta ditanggung oleh seorang kepala keluarga. Apalagi kebutuhan itu sifatnya primer. Dalam kebudayaan orang Timor Leste, adat istiadat menjadi ajang pengeluaran uang yang paling besar. Adat istiadat adalah sifatnya wajib dan harus dilakukan jika yang bersangkutan masih ada hubungannya.

Kelima, apresiasi sekolah dan kementerian yang berkompeten terhadap kinerja guru. Menghargai kinerja orang lain adalah salah satu wujud rasa kepedulian terhadap hasil karyanya. Untuk mengetahui informasi ini, peneliti melakukan wawancara kepada informan dengan pertanyaan "Apakah guru pernah memperoleh reward atau 


\section{LingTera, 5 (2), 2018 - 168}

Aniceto Jordão de Araújo

bonus dari sekolah atau departemen yang berkompeten terhadap hasil kerja guru?" Apabila Tidak, mengapa? Narasumber menjawab dengan santai "Tidak, sampai sekarang sekolah belum membuat hal seperti itu. Belum punya rencana seperti itu. Yang punya saat ini hanyalah evaluasi kepegawaian tapi untuk sekolah belum memberikan hal-hal motivasi apa yang menjadi pertanyaan itu tidak terjadi", kata PF. (W2/PF/210116/P43).

Keenam, implikasi lingkungan sekolah dan situasi keluarga guru terhadap proses pembelajaran. Lingkungan adalah tempat dimana orang tinggal dan melakukan aktivitas dalam kehidupan setia harinya. Lingkungan pada umumnya dijadikan sebagai sebuah patokan berjalan baik tidaknya suatu proses kehidupan dan pembelajaran. Informan PF hanya menyoroti lingkungan siswa dengan mengatakan bahwa "Lingkungan itu jadi barometer untuk mengembangkan para siswa. Prestasi dari siswa tidak hanya tergantung dari sekolah tapi lingkungan di rumah, lingkungan sekitar rumah itu sebagai sebuah proses untuk membentuk mental siswa tersebut. Jadi bukan hanya sekolah yang membentuk tapi lingkungan juga sebagai faktor determinan atau faktor penentu siswa tersebut" (W1/PF/140116/P23).

Ketujuh, sanksi sekolah terhadap guru yang mengabaikan tugas. Sanksi merupakan salah cara pembentukan karakter. Dalam hal ini diterapkan atau diberikan pada oknum guru yang nakal dan tidak menunaikan kewajibannya sebagai guru. Menjadi guru bukan sekedar berdiri di depan kelas kemudian menyampaikan materi kepada siswa. Akan tetapi, harus menjadi suatu panggilan jiwa dari hati nurani sebagai pendidik. Hal ini berlaku bagi guru-guru di Timor Leste karena menurut mereka menjadi guru lebih mudah dibandingkan dengan profesi lainnya. Itulah kenyataan yang sebenarnya terjadi di negara ini, sehingga mereka tidak mengerti dan memahami kompetensi-kompetensi yang harus dimiliki oleh guru. Dengan begitu akan jelas tergambarkan lewat tindak-tanduknya yang tidak mentaati dan mengabaikan tugasnya sebagai seorang pengajar. Berdasarkan observasi peneliti selama berada di sekolah ini terdapat beberapa orang guru dari program produksi (teknik) sering mengabaikan dan bahkan tidak masuk mengajar. Padahal, guru tersebut jam mengajarnya kurang dari 12 jam per-minggunya. Tindakan guru ini oleh sekolah tidak diambil atau pemberian sanksi indisipliner. Kepala sekolah sebagai top manager seharusnya memberikan sanksi kepadanya sesuai dengan tingkat kesalahannya. Malah sekolah membiarkan perbuatan tersebut berlarut-larut sampai sekarang.

\section{Latar Belakang Pendidikan dan Karakter Siswa}

Latar belakang pendidikan dan karakter siswa. Kebudayaan merupakan wujud realisasi kebiasaan sehari-hari yang disampaikan lewat idea atau gagasan dalam bentuk nyata sesuatu. Ide atau gagasan itu diwujudkan dalam kehidupan sehari-hari. Namun, kebudayaan ituakan selalu beradaptasi dengan proses perkembangan zaman. Lebih parahnya budaya ini semakin subur dan menprihatinkan dalam kehidupan setelah dalam kemerdekaan. Budaya malu mulai tergerus oleh budaya dansa Kizomba ala Cuba dan Amerika Latin/Selatan yang semakin menjerumuskan generasi muda dalam kehidupan bebas. Kebiasaan ini juga semakin merasukijiwa kehidupan siswa-siswi sebagai pelajar. Sehingga proses belajar merekapun akan terganggu sebagai akibat implikasi dari aktivitas berdansa semalam suntuk. Informan FF bahwa "Itu sudah otomatis, dansa semalam suntuk terus pagi ikut proses pembelajaran itu susah sekali bahwa dia konsentrasinya itu tidak ada karena selama satu malam anda dansa sampai pagi habis itu anda ke sekolah. Itu pertama dia disana harus tidur, dia tidak akan, kalau guru itu paksa pun untuk mendengar tapi konsentrasinya minim sekali. Bahkan tidak ada satupun masuk karena tenaganya sudah kurang, konsentrasinya sudah tidak ada. Itu tidak akan berhasil" (W1/FF/130116/P22). Selanjutnya, "Secara psikologiko jika anda tidak mempersiapkan mental, fisik itu sangat sulit terganggu. Bilamana anda menghabiskan waktu-waktu sepanjang malam di tempat-tempat lain dan sampai pagi lalu paginya anda langsung ke sekolah. Itu secara psikologiko sangat mempengaruhi besar dalam proses di sekolah" (W1/PF/140116/P22), kata PF.

\section{SIMPULAN}

Berdasarkan pembahasan tersebut, maka dapat disimpulkan bahwa (1) STM Negeri Dili, Timor Leste masih berusia muda sehingga dapat menjadi penghambat pelaksanaan pembelajaran bahasa Inggris; (2) Proses pembelajaran bahasa Inggris di STM Negeri Dili, Timor Leste belum mempunyai kurikulum; (3) Guru kurang kreatif dalam pembelajaran bahasa Inggris; (4) Perangkat pembelajaran dalam bahasa Inggris di STM Negeri Dili, Timor Leste belum memadai; (5) Usaha di dalam peningkatan kompetensi belum maksimal; (6) Rendahnya pengetahuan dan pe- 


\section{LingTera, 5 (2), 2018 - 169}

Aniceto Jordão de Araújo

mahaman guru menjadi penyebab utama terhadap mutu lulusan para siswa. Hal ini ditambah lagi dengan pengaruh lingkungan sosial yang berbudaya pesta dansa terhadap perilaku siswa.

\section{DAFTAR PUSTAKA}

Eko M, A. A. (2016). Pengembangan bahan ajar bahasa Inggris berbasis kompetensi kerja untuk mempersiapkan peserta didik menempuh on the job trining di bagian front office hotel (Studi pengembangan di International Hotel Management School). Dissertation, Universitas Sebelas Maret).

Harianti, R., \& Amin, S. (2016). Pola asuh orangtua dan lingkungan pembelajaran terhadap motivasi belajar siswa. Curricula: Journal of Teaching and Learning, 1(2).

Islam, S. (2017). Karakteristik pendidikan karakter; menjawab tantangan multidimensional melalui implementasi Kurikulum 2013. Jurnal Edureligia, 1(2), 89-100.

Nirmalasari, M. (2011). Pengembangan model memorization learning dalam meningkatkan pemahaman peserta didik pada pelajaran kimia SMA. Wahana Fisika, 2, 178-190.

Purwanti, S. (2016). Peranan kepala madrasah terhadap kinerja guru. AL-IDARAH: Jurnal Kependidikan Islam, 6(1).

República Democrática de Timor-Leste. (2010). Decreto-Lei 8/2010. Que aprova o plano curricular, regime de implementação $e$ modelo de certificação, organização $e$ avaliação das escolas secundárias técnico-vocacionais. Dili: Timor Leste.

Sanjaya, W. (2011). Pembelajaran dalam implementasi kurikulum berbasis kompetensi. Jakarta: Kencana Prenada Media Group.

Sugiyono. (2013). Metode penelitian pendidikan: Pendekatan kuantitatif, kualitatif, dan $R$ \& $D$. Bandung: Alfabeta.

Sugiyono. (2015). Metode penelitian kombinasi (Mixed methods). Bandung: Alfabeta 